\title{
41. LOADING EXPERIMENTS ON CARBONATE OOZE AND CHALK FROM LEG 130, ONTONG JAVA PLATEAU ${ }^{1}$
}

\author{
Ida L. Lind ${ }^{2}$
}

\begin{abstract}
Consolidation experiments, in which the pore water is slowly squeezed from a sample, as well as undrained loading tests, where pore water under a high pressure is prevented from leaving a sample, have been conducted on samples of Ontong Java Plateau ooze and chalk. Hole 803D was sampled down to $519 \mathrm{mbsf}$ and Holes 807A and 807C down to $945 \mathrm{mbsf}$. Consolidation curves relating uniaxial stress to matrix porosity fall along a single trend for the Site 803 samples. The matrix porosity was determined from the bulk porosity by subtracting the intramicrofossil porosity, obtained by electron microscopy and image analysis of polished surfaces. No difference in the compaction trend was found between ooze and chalk, and no obvious indication of chemical compaction could be deduced from the compaction curves. Undrained loading leads to fracturing in the chalk samples, whereas ooze samples remain unfractured under these conditions.
\end{abstract}

\section{INTRODUCTION}

The mechanical properties of deep-sea carbonate sediments have been studied by several authors. Schlanger and Douglas (1974) described material from the Magellan Rise. They defined an upper 200-m-thick, shallow-burial realm dominated by gravitational (mechanical) compaction, where porosities are reduced from around $80 \%$ near the seafloor to around $60 \%$ at $200 \mathrm{~m}$ below seafloor (mbsf), and where soft ooze is transformed to stiff ooze and chalk. From 200 to $1000 \mathrm{mbsf}$, they defined the deep-burial realm dominated by chemical processes, where porosities are gradually reduced from $60 \%$ at 200 mbsf to around $40 \%$ at $1000 \mathrm{mbsf}$, and chalk is transformed to limestone. Small calcite crystals are dissolved, and the calcite was reprecipitated on larger crystals.

Hamilton (1976) discussed the amount of rebound experienced by sediments because of their removal from the pressure of overlying sediments. From a survey of the available data on consolidation tests on marine sediments, he concluded that calcareous sediments experience a rebound in porosity increasing from $0 \%$ for samples from near the seafloor to $4 \%-5 \%$ for samples from a depth of $300 \mathrm{mbsf}$. No data were listed for samples from greater depths, but an even greater rebound would be expected. Hamilton estimated the rebound experienced by a sample upon removal from its natural burial setting by observing the rebound of the sample after the removal of artificially applied stress during consolidation testing. The basis for this method was the observation that rebound curves were parallel regardless of applied maximum stress and regardless of initial sample disturbance.

Wetzel (1989) performed consolidation experiments using an oedometer on ooze and chalk from eastern Pacific Deep Sea Drilling Project (DSDP) Sites 504 and 505, which are located in water depths of 3460 and $3520 \mathrm{~m}$, respectively. The sediments are thin $(250 \mathrm{~m})$, and at Site 504 the basement temperature is higher $\left(60^{\circ}-90^{\circ} \mathrm{C}\right)$ than at Site $505\left(15^{\circ}-20^{\circ} \mathrm{C}\right)$. Wetzel measured the preconsolidation stress for each sample and calculated the overburden stress from on-board bulk-density determinations. The difference between the two stresses was attributed to chemical compaction; that is, the dissolution of material at grain contacts and precipitation in pore space. The amount of creep was calculated from long-term compression tests. The volume of cement at a given stress was calculated as the difference

\footnotetext{
${ }^{1}$ Berger, W.H., Kroenke, L.W., Mayer, L.A., et al., 1993. Proc. ODP, Sci. Results, 130: College Station, TX (Ocean Drilling Program).

${ }^{2}$ Instituttet for Geologi og Geoteknik, Danmarks Tekniske Højskole, Bygning 204, DK-2800 Lyngby, Denmark.
}

between the creep-corrected void ratio, measured from consolidation experiments, and the void ratio measured in the field. A 1.3-times steeper line relating overburden stress to the amount of cement was obtained for the low heat-flow Hole 505 as compared with the high heat-flow Hole 504. This demonstrates the positive influence of temperature on chemical compaction.

Several studies have been conducted at the Ontong Java Plateau, where a more than 1-km-thick Cretaceous and Cenozoic sequence of generally pure calcium carbonate sediments is present. Because of the relatively shallow water depth over the basaltic plateau and the high production of foraminifers and nannoplankton in the equatorial waters, a near-ideal sequence is present for the study of the physical properties of pelagic carbonates. The lithology is foraminiferal nannofossil ooze, foraminiferal nannofossil chalk, and limestone.

Hamilton et al. (1982) studied the influence of foraminifer content on sonic velocity in the Ontong Java Plateau; they concluded that hollow foraminifers act as solid particles in transmitting sound. On the top of the plateau, high porosities and high sonic velocities were found because of the large proportion of foraminifers, whereas the deeper, more foraminifer-poor sites had lower porosities and velocities. Thus, the intra-foraminiferal porosity influenced the total porosities but not the velocities. Bachman (1984) measured the intraforaminiferal porosity of material from the Ontong Java Plateau by relating the porosity of a sample of foraminifers to the porosity of a sample of glass beads of the same diameter.

Kim et al. (1985) found that the decrease in bulk porosity on the Ontong Java Plateau appears to be related more to depth of burial than to the age of the strata. For the porosity decline below $200 \mathrm{mbsf}$, they refer to a pressure solution process (chemical compaction).

Fulthorpe and Schlanger (1989) studied the acoustic properties from DSDP Sites 289 and 586 on the Ontong Java Plateau. They noted the presence of calcite overgrowth on discoasters and the dissolution of nannofossils in Site 586 samples from a depth of $150 \mathrm{mbsf}$, and the transition from soft ooze to stiff ooze and chalk at roughly $250 \mathrm{mbsf}$.

Smits et al. (1988) performed compaction experiments on moldic limestone as well as three different chalks. They established that subsequent to pore collapse, samples of similar lithology but different initial porosity tend to follow the same curve relating porosity to vertical effective stress. This curve seems to be characteristic for each type of limestone (Fig. 1).

Pore collapse and fracturing resulting from undrained loading are not well understood. From experiments on chalk from Stevns, Denmark, with $50 \%$ porosity, Lind (1988) obtained horizontal fracturing in samples when the uniaxial stress was oriented along the vertical 

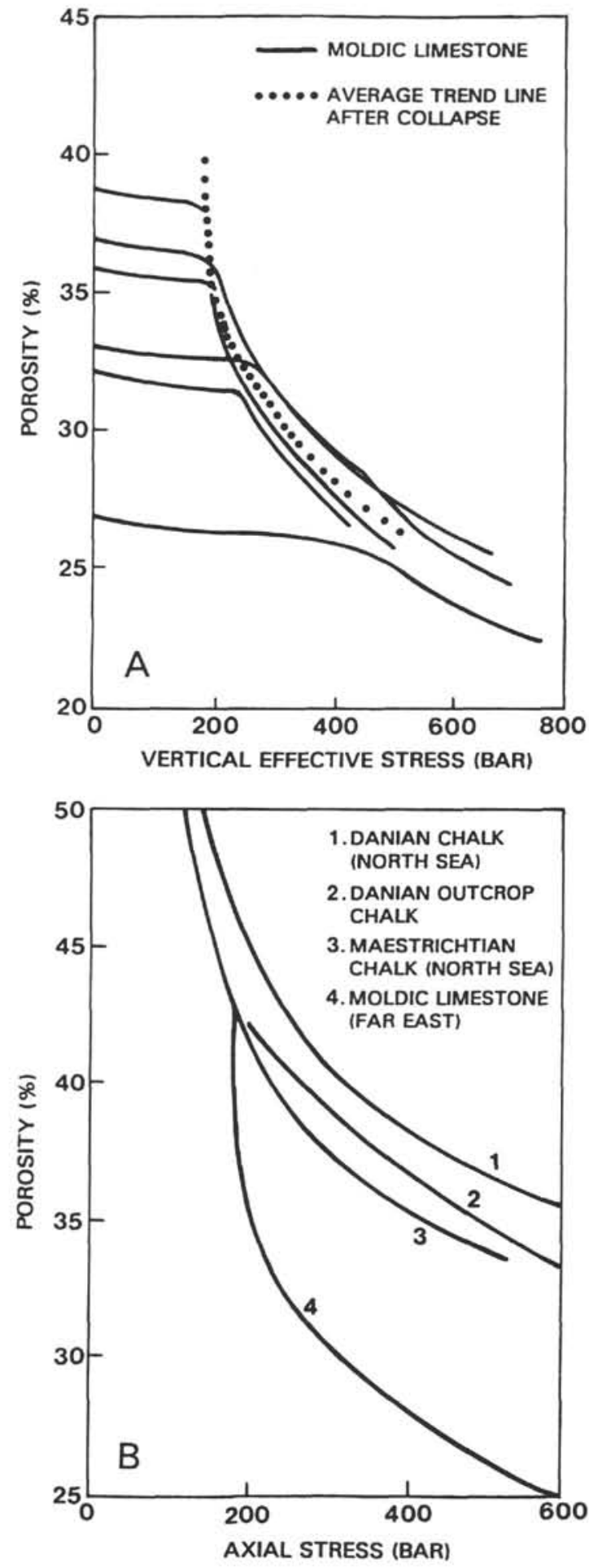

Figure 1. Typical carbonate compaction behavior. A. Porosity vs. vertical effective stress for moldic limestones. B. Porosity-stress trend lines for various carbonate rock types. Loading rate $1000 \mathrm{br} / \mathrm{hr}$. After Smits et al. (1988).

direction of the samples, if the pore pressure rose as a consequence of loading, and if the liquid pressure exceeded the effective vertical stress. A very marked effect was seen when the pore pressure was more than twice the effective stress. When the uniaxial stress paralleled the horizontal direction of the samples, closely spaced inclined fractures in conjugate directions were obtained. The fracturing was difficult to explain from geotechnical theory. It was argued that the measured anisotropy in tensile strength combined with an effect of the high-pressure water might cause the observed fractures. The Ontong Java Plateau carbonate sediments form in a setting with very high natural pore pressures and a wide range of porosities, so material from this locality was considered ideal for a closer definition of the conditions controlling fracturing.

From shipboard descriptions of Ocean Drilling Program (ODP) Leg 130 cores, a gradual change is seen from foraminifer-bearing nannofossil ooze to chalk and from chalk to limestone. The depths of transition are dependent on the water depth and on the age of the sediment (Kroenke, Berger, Janecek, et al., 1991). The ooze to chalk transition occurs at 200-300 mbsf. The chalk/limestone transition was seen only in Hole $807 \mathrm{C}$, occurring here at a depth of roughly 1100 mbsf. A bottom hole temperature of $30^{\circ} \mathrm{C}$ was measured in the basalt of Hole $807 \mathrm{C}$. These sediments should be well suited for a comparison of natural porosity reduction with that obtained artificially in consolidation experiments.

In the present study, fully drained consolidation tests to a maximum $80-\mathrm{MPa}$ uniaxial stress as well as undrained loading tests with pore pressures up to a maximum of $40 \mathrm{MPa}$ were performed. The aim of the consolidation experiments was to characterize the sediments from their consolidation curves and to estimate the importance of chemical compaction. This characterization was supported by data from the analysis of back-scatter electron images of polished surfaces. Undrained tests were conducted to study the resulting fracture patterns.

The present samples from the Ontong Java Plateau cover a time frame from the Eocene to the Pleistocene. Six sample depths in Hole 803D span the interval from 15 to 519 mbsf. Nine sample depths from Hole $807 \mathrm{~A}$ plus one from Hole $807 \mathrm{C}$ span the interval from 15 to 945 mbsf. Both intervals fall within the practically linear porosity depth trends estab.ished from the shipboard physical properties measurements (Kroenke, Berger, Janecek, et al., 1991). The uppermost samples have porosities of roughly $70 \%$; the deepest samples have porosities of roughly $50 \%$ in both holes. Calcium carbonate contents were between $85 \%$ and $95 \%$ for the sampled sections (Kroenke, Berger, Janecek, et al., 1991).

\section{PROCEDURES}

Samples for the experiments were collected as whole-round, 6-cm-long core sections sampled shortly after core recovery. The samples were kept in capped pieces of liner to avoid damage and change of shape. The liners were sealed in wax to avoid drying.

The samples were stored in a refrigerator on board and again in a refrigerator after shipment to the laboratory. Samples for the experiments were cut with a steel pipe in the soft ooze, whereas samples from the harder chalk were drilled out of the core sections. The experiments were run as soon as possible after cutting or drilling. From each sample three plugs were drilled: one for drained compaction experiments, one for high fluid pressure undrained loading tests, and one for reference. Sampling was successful for all Hole 803D whole rounds. For the Hole $807 \mathrm{~A}$ material, sampling succeeded except for two depths, 519 and $625 \mathrm{mbsf}$, which were neither soft nor hard, where sampling had to be abandoned because the samples crumbled under the attempts. At most intervals two or three samples were obtained; in four intervals only one sample was useful. If only two samples were obtained, a non-plug-shaped sample served as the reference; if only one plug was obtained, only a drained compaction test was conducted (Table 1).

All experiments were conducted at the Danish Geotechnical Institute. All tests were uniaxially confined and done in a stainless-steel compaction cell (Fig. 2). The cell was equipped with a fluid pressure monitoring system. Pore pressures at the upper and lower ends were measured independently. All experiments were done at room temperature. The cylindrical samples, $2.5 \mathrm{~cm}$ in diameter and $5 \mathrm{~cm}$ long, were 
Table 1. Loading experiments data.

\begin{tabular}{|c|c|c|c|c|c|c|c|}
\hline \multirow[b]{2}{*}{$\begin{array}{l}\text { Sample } \\
\text { depth } \\
\text { (mbsf) }\end{array}$} & \multicolumn{3}{|c|}{ Initial porosity } & \multirow[b]{2}{*}{$\begin{array}{c}\text { Compaction } \\
\text { test no. }\end{array}$} & \multirow[b]{2}{*}{$\begin{array}{c}\text { Final } \\
\phi \\
(\%)\end{array}$} & \multirow[b]{2}{*}{$\begin{array}{c}\text { Undrained } \\
\text { loading } \\
\text { test no. }\end{array}$} & \multirow[b]{2}{*}{$\begin{array}{l}\text { Resulting } \\
\text { fractures }\end{array}$} \\
\hline & $\begin{array}{l}\text { PP } \\
(\%)\end{array}$ & $\begin{array}{c}\text { o-bulk } \\
(\%)\end{array}$ & $\begin{array}{c}\phi \text {-matrix } \\
(\%)\end{array}$ & & & & \\
\hline \multicolumn{8}{|l|}{ 130-803D- } \\
\hline 15 & $66-67$ & 70 & 64 & ID & 50 & $2 \mathrm{U}$ & \\
\hline 118 & $61-65$ & 64 & 62 & $3 \mathrm{D}, 4 \mathrm{D}$ & 64,52 & $5 \mathrm{U}$ & \\
\hline 212 & $61-61$ & 63 & 60 & 8D & 50 & $6 \mathrm{U}, 9 \mathrm{U}$ & $\mathrm{X}$ \\
\hline 322 & 52 & 58 & 55 & 10D & 43 & $7 \mathrm{U}$ & $\mathrm{X}$ \\
\hline 412 & $48-50$ & 49 & 48 & 11D & 41 & & \\
\hline 519 & $51-52$ & 53 & 48 & $14 \mathrm{D}$ & 41 & & \\
\hline \multicolumn{8}{|l|}{$130-807 \mathrm{~A}-$} \\
\hline 15 & $68-69$ & 63 & 59 & $12 \mathrm{D}$ & 52 & $13 \mathrm{U}$ & \\
\hline 100 & $66-67$ & 66 & 61 & $15 \mathrm{D}$ & 50 & $16 \mathrm{U}$ & \\
\hline 206 & 60 & 59 & 55 & $17 \mathrm{D}, 18 \mathrm{D}$ & 48,39 & $19 \mathrm{U}$ & \\
\hline 319 & $55-61$ & 62 & 56 & $28 \mathrm{D}$ & 50 & & \\
\hline 414 & $51-57$ & 56 & 44 & $20 \mathrm{D}$ & 49 & $25 \mathrm{U}$ & $\mathrm{x}$ \\
\hline 519 & $52-55$ & & & & & & \\
\hline 625 & $51-52$ & & & & & & \\
\hline 722. & $48-50$ & 51 & 45 & $21 \mathrm{D}$ & 39 & $26 \mathrm{U}$ & $\mathrm{X}$ \\
\hline 815 & & 52 & 48 & 22D & 38 & & \\
\hline \multicolumn{8}{|l|}{$130-807 \mathrm{C}$ - } \\
\hline 945 & $48-51$ & 49 & 42 & 23D & 40 & $27 \mathrm{U}$ & $\mathrm{x}$ \\
\hline $\begin{array}{r}\text { Notes: Ship } \\
\text { initial b } \\
\text { was det } \\
\text { Undrai } \\
\text { sample }\end{array}$ & $\begin{array}{l}\text { rd phys } \\
\text { porosity } \\
\text { ined fro } \\
\text { loading } \\
\text { marke }\end{array}$ & $\begin{array}{l}1 \text { propert } \\
\text { nd final p } \\
\text { bulk por } \\
\text { sts led to } \\
\text { y the let }\end{array}$ & $\begin{array}{l}\text { porosity d } \\
\text { sity from } \\
\text { y and intra } \\
\text { actically n } \\
\text { "X". }\end{array}$ & $\begin{array}{l}\text { (PP) from } \mathrm{Kr} \\
\text { ts were determ } \\
\text { sil porosity, w } \\
\text { hange in poro }\end{array}$ & $\begin{array}{l}\text { enke, Ber } \\
\text { ed volum } \\
\text { the latte } \\
\text { y. Undra }\end{array}$ & $\begin{array}{l}\text { r, Janecek, e } \\
\text { rically. Initia } \\
\text { btained fron } \\
\text { ed tests resul }\end{array}$ & $\begin{array}{l}\text { (1991). T } \\
\text { latrix porosi } \\
\text { nage analysi } \\
\mathrm{g} \text { in fractur }\end{array}$ \\
\hline
\end{tabular}

cut in two cylindrical halves, and the halves fitted back together with a thin layer of pyrite powder at the interface to make compaction features that developed during the experiment visible. The samples were fitted into the steel chamber, and the entire system was saturated with seawater. A constant strain rate of maximally $5 \times 10^{-6} \mathrm{~s}^{-1}$ was applied for the tests. Two external linear voltage deformation transducers were used.

During the compaction tests, the chamber was drained through the upper filter (Fig. 2). No buildup of pore pressure was recorded by the pressure transducers located near each of the two outlets from the cell. The compaction was completed when the sample porosity was reduced to near $50 \%$ or near $40 \%$. Typical compaction curves are depicted in Figure 3. For the soft samples, the first part of the compaction curves are not reliable because it was difficult to obtain a perfect cylindrical shape that exactly fitted the chamber.

After the tests were terminated, the porosity was measured on the now perfectly shaped and water-saturated samples using a balance and caliper, assuming a grain density of $2.7 \mathrm{~g} / \mathrm{cm}^{3}$ and a water density of $1.0 \mathrm{~g} / \mathrm{cm}^{3}$. The original porosity was calculated from the final porosity and the original weight of the sample under the assumption of total water saturation. The calculated initial porosities do not always equal but generally correspond to shipboard physical properties data (Table 1).

The undrained tests were conducted in the following manner. From consolidation data of the analogous drained sample, the deformation needed to totally fit the sample to the chamber was calculated. This initial deformation was done under drained conditions. The sample was subsequently loaded to its natural stress and pore pressure by simultaneously loading and increasing the fluid pressure. The natural uniaxial stress was estimated from the bulk-density data of Kroenke, Berger, Janecek, et al. (1991) and by assuming a water density of $1.0 \mathrm{~g} / \mathrm{cm}^{3}$. Also, the fluid pressure was estimated by assuming a water density of $1.0 \mathrm{~g} / \mathrm{cm}^{3}$. During this loading step, care was taken to maintain a constant low effective stress, so that the natural effective stress was obtained gradually. Upon reaching the simulated natural state, the steel chamber was isolated from fluid flow and loading continued until a fluid pressure of $40 \mathrm{MPa}$ was reached. Because of the compressibility of the water, effective stress will also increase during this process. During the subsequent off-loading, care was taken to maintain a positive effective stress lower than the one applied during the previous pressure increase. Curves describing the undrained loading experiments are presented in Figure 4.

Subsequent to the porosity determination, all samples were dried at $50^{\circ} \mathrm{C}$ and a small piece removed for scanning electron microscopy (SEM). The sample was impregnated with epoxy and halved, and thin sections as well as polished surfaces were prepared. The polished surfaces were described, and selected samples were imaged by backscatter electron microscopy (BSE) at Danish Technological Institute, and digital images were recorded for analysis.

Image analyses were conducted on selected samples using BSE images recorded over five areas on each sample at magnifications of $200 \times$ and $3000 \times$, using the PIPPIN interactive image processing system. PIPPIN is based on the principles described by Niblack (1986). The intraparticle porosity was obtained by analysis of the BSE images at $200 \times$ magnification. Because the low magnification does not resolve the very fine interparticle porosity, it is easy to calculate the fully resolved and therefore darker intraparticle porosity.

In principle, the interparticle porosity should be obtainable from the $3000 \times$ magnification images. Problems result from the poor resolution between grains and epoxy, which is unavoidable at the very small grain size of the samples (see Plate 1, Figs. 1 and 4). The poor resolution is caused by the diffuse edges that result when the grain/epoxy interface cuts the polished surface at a skewed angle. Interparticle porosity, therefore, was not determined by image analysis.

At each sampling depth, the original intrafossil porosity was measured on five areas represented as 200x magnification BSE images. For intervals in the firm chalk, the reference sample was used. For the less well-preserved ooze samples, the samples that were subjected to undrained compaction were used because they had suffered little net deformation after restoration to their natural state. 


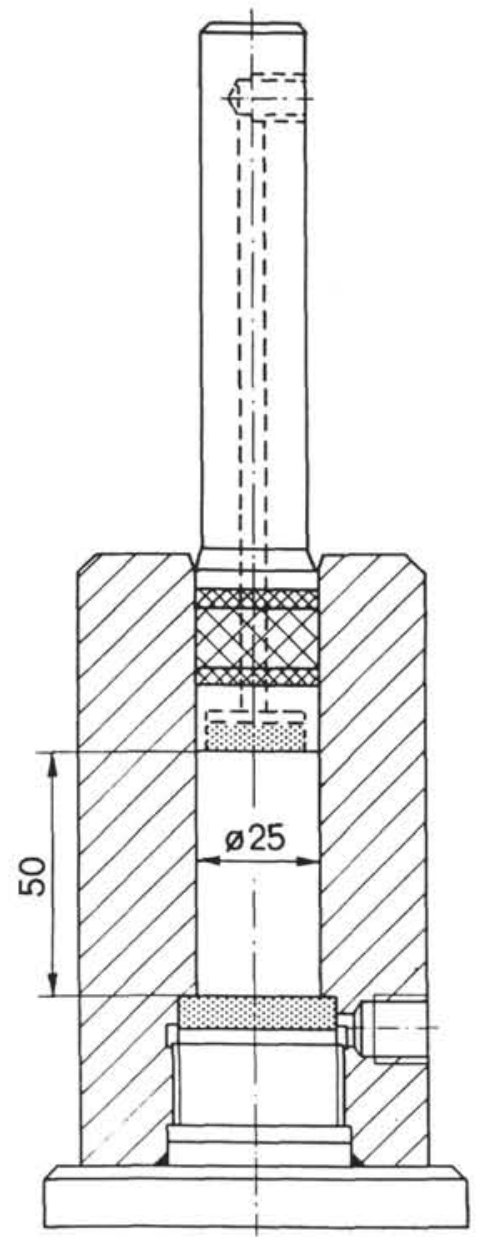

Figure 2. The stainless-steel chamber used for the present experiments. Fully drained compaction tests can be run as well as tests involving high fluid pressure.

The selection of intrafossil porosity is illustrated on Figure 5. The initial interparticle porosity was calculated from the intraparticle porosity values obtained for the five areas in combination with bulk porosity.

\section{RESULTS}

A summary of all experiments is given in Table 1.

\section{Compaction Tests}

Porosity vs. uniaxial stress curves for the drained tests are shown in Figure 6. As expected, yield stress increases with sample depth, whereas the curves for the subsequent compaction trend for samples from Sites 807 and 803 display a rather scattered pattern. No obvious difference is present between the trends for the two sets of samples.

Thin sections and BSE images (Plates 1 and 2) show that although the major part of the porosity is interfossil, a minor yet substantial part of the porosity is intramicrofossil porosity. Microfossils are preserved undisturbed during the loading experiments, so the intrafossil porosity is irrelevant for compaction. Therefore, the total porosity is less meaningful for the interpretation of consolidation curves than the interparticle matrix porosity. New curves were constructed that relate the interfossil matrix porosity to the uniaxial stress (Fig. 7). The curves on Figure 7A, representing samples from Site 803, show a much more regular pattern than those in Figure $6 \mathrm{~A}$, and the compaction curves now all fall along the same trend. The curves representing samples from Site 807 display the same general trend as those of Site 803; contrary to these, however, they show more scattering, which is similar to Figure $6 \mathrm{~B}$, where stress is related to total porosity.

The difference in patterns between samples from Sites 807 and 803 is probably related to the uncertainty involved in the measurement of the intraparticle porosity. In Figure 8 the intrafossil porosity is plotted vs. depth for the two sites. The average value for the five measurements is shown, and the standard deviation is indicated by an error bar. For Site 807 the average intrafossil porosities are between two or three times higher than those for Site 803, and the standard deviations are generally much larger as well. The uncertainty in the determination of the intrafossil porosity is much higher for Site 807 than for Site 803 .

Neither the bulk porosity vs. stress curves (Fig. 6) nor the matrix porosity vs. stress curves (Fig. 7) separate the compaction trends of ooze samples from the trends of chalk samples. The deeper chalk samples yield at stresses that are higher than their natural effective overburden stress. The fact that they yield at a curve that cannot be distinguished from the ooze compaction trend, indicates that the high yield stress may oe a consequence of wall friction and creep rather than excess preconsolidation. Thus, the compaction curves are not direct reproductions of the natural compaction process, but analogues, giving information on the properties of the sediments. No evidence of chemical compaction was seen from BSE analysis of the polished samples.

Within the single sample the compaction is unevenly distributed. The curved shape of the former planar pyrite lining between the two halves of the plug (Plate 3) indicates that friction between the sample and the chamber wall is of importance. In thin sections (Plate 2), local differential compaction is also seen by offset along faults and along microfossils. The relative deformation of the upper and lower halves was determined by measuring the location of the pyrite seam on the polished halved plugs under the assumption that the interface can be approximated as a part of a sphere; the strain, $\varepsilon$, was then calculated for each half. The strain values calculated for the lower halves, $\varepsilon_{\mathrm{L}}$, are now plotted against those of the upper halves, $\varepsilon_{\mathrm{U}}$, in Figure 9 , and a linear trend is observed with a correlation coefficient of $R=0.9$. Not surprisingly, the upper halves are more readily deformed than the lower, because the stress was applied from the top during the loading tests. The strain of the upper half is generally $15 \%$ (absolute) higher than the strain of the lower half.

Figure 10 displays the porosity vs. the logarithm of the uniaxial effective stress for all drained loading experiments. A roughly linear trend is seen. Native, uncompacted samples are also plotted. The native samples fall along a trend that is slightly steeper than the artificial compaction trend. The rate of creep can be estimated using Figure 10 by the following reasoning: At an effective stress of $1.1 \mathrm{MPa}$, the line representing native samples are separated from the line representing artificially compacted samples by $4 \%$ porosity. This means that fresh samples with a porosity of $60 \%$ were subjected to an effective uniaxial stress that is equal to the stress experienced by artificially compacted samples of $64 \%$ porosity. The change from $64 \%$ to $60 \%$ porosity corresponds to a strain of $15 \%$. The artificially compacted sample was left to creep for around $1 \mathrm{~min}$ and the age of the $60 \%$ porosity samples is about $10 \mathrm{Ma}$, corresponding to $1013 \mathrm{~min}$. Thus, the two data points are separated by 13 logarithmic decades of time. A creep of $1.1 \%$ per decade can accordingly be calculated. In the same manner, a creep of $0.9 \%$ per decade is calculated from the $50 \%$ porosity samples. These results indicate a general creep of about $1 \%$ per decade of time.

An estimation of rebound in porosity was attempted using all of the consolidation curves with the method described by Hamilton (1976). The resulting values are plotted on Figure 11 and show rebound values of $<0.1 \%$ for all samples. Also, an overall increase in rebound with depth is seen. 

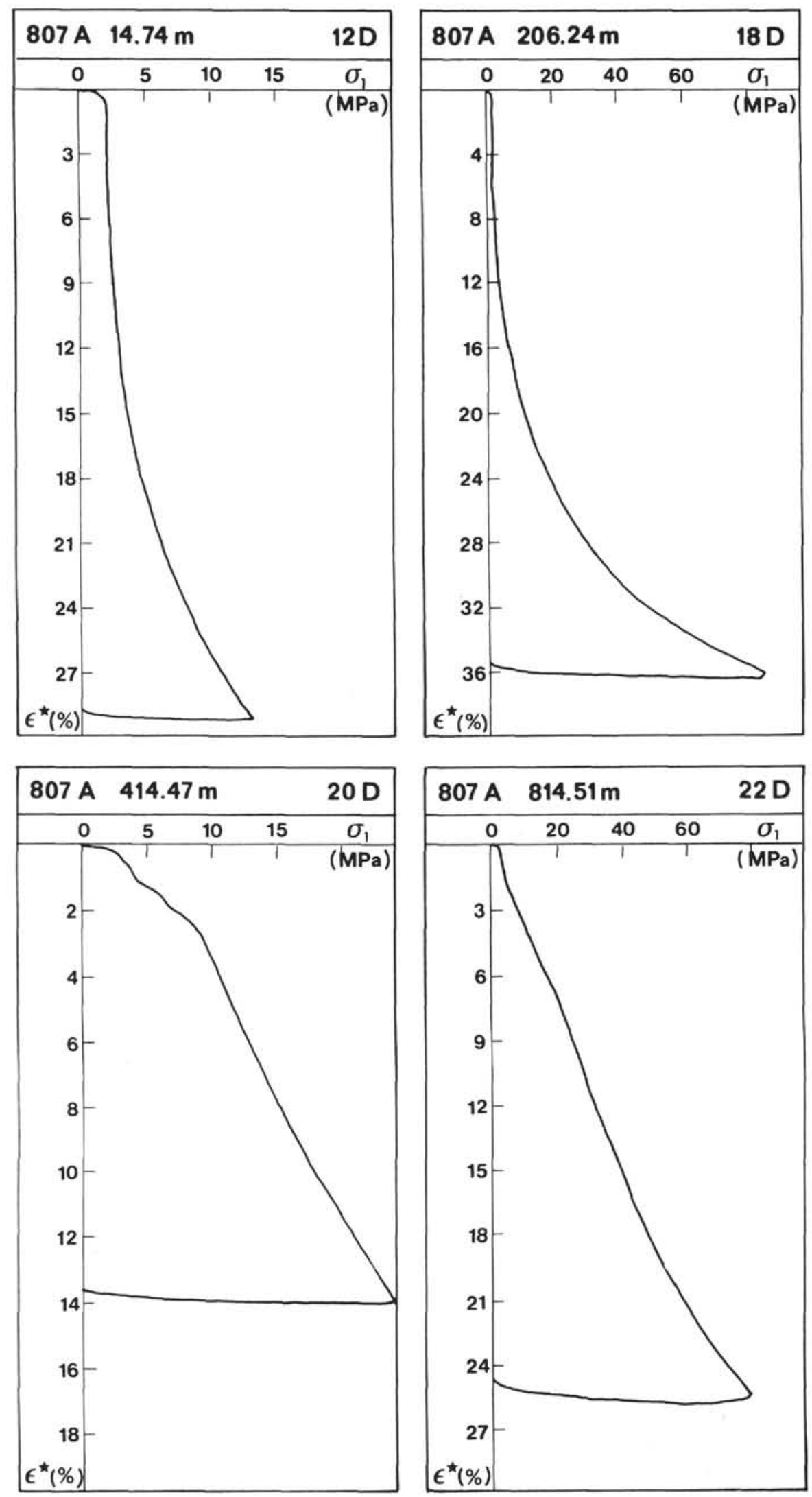

Figure 3. Consolidation curves for samples from different depths in Hole 807A. The uniaxial stress, $\sigma_{1}$, and the resulting strain, $\varepsilon^{*}$, are recorded on linear axes. After the initial fitting, the two ooze samples of Tests 12D and 18D deformed smoothly, whereas the slower pore collapse and sample fitting in chalk is reflected in the uneven initial curves of Tests 20D and 22D. The unloading curves are only slightly inclined in all four samples. 

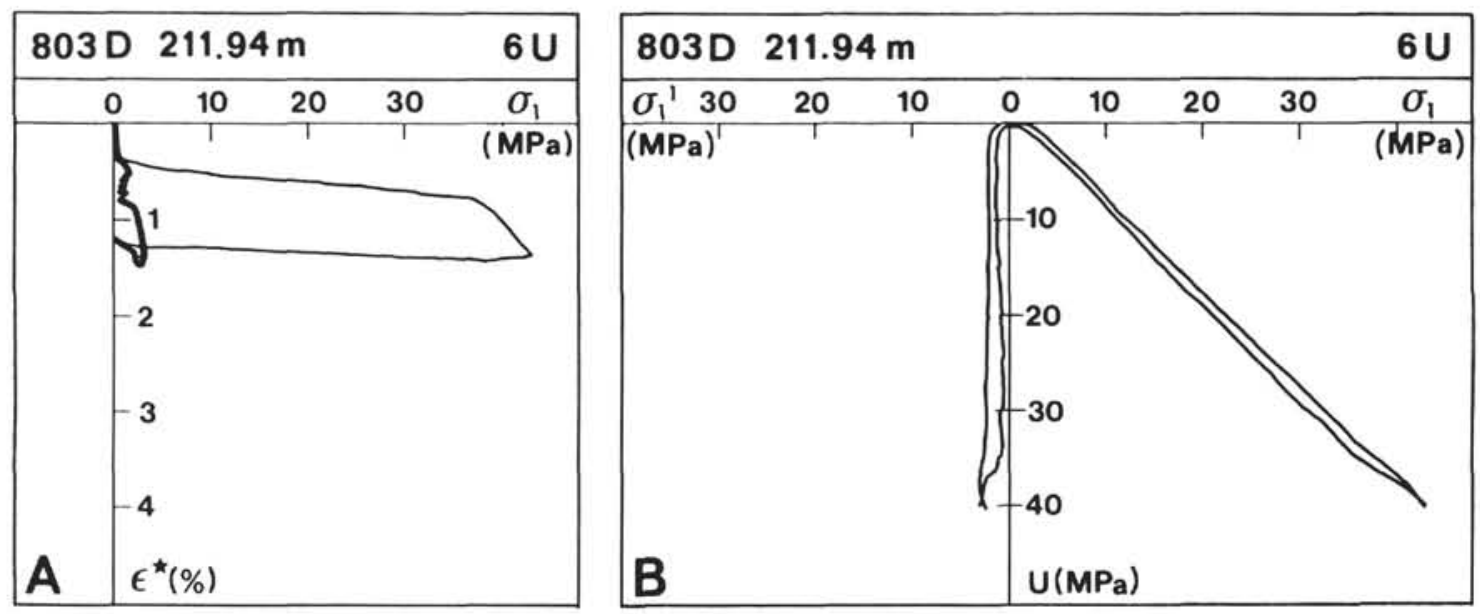

Figure 4. Undrained loading experiments. A. Uniaxial stress, $\sigma_{1}$, plotted as a light line vs. the resulting strain, $\varepsilon^{*}$. The heavy line represents the effective stress, $\sigma_{1}{ }^{\prime}$, calculated from $\sigma_{1}$ by subtracting the fluid pressure, $u$. B. The course of the experiment is depicted by plotting $\sigma_{1}$ and $\sigma_{1}{ }^{\prime}$, respectively, vs. $u$. The experiment is initiated at zero and follows the upper curves during loading and the lower curves during unloading back to zero.

\section{Undrained Loading Tests}

Undrained loading experiments gave no fracturing in the most shallow ooze samples, whereas a conjugate pattern of fractures resulted in the deeper chalk samples (Plate 3 ). A densely spaced pattern of horizontal fractures as those described by Lind (1988) was not found in any sample.

Fractures were not observed in samples from depths corresponding to a natural effective stress of $<1.3 \mathrm{MPa}$ (206 mbsf in Hole 807A), but they were found in samples from a natural effective stress of $>1.4 \mathrm{MPa}$ (212 mbsf in Hole 803D) (Table 1). These data indicate that a natural effective stress of about $1.5 \mathrm{MPa}$ is required to consolidate the material sufficiently for fracture formation under the confined conditions of these experiments.

\section{DISCUSSION}

Compaction curves obtained from the present samples show a trend comparable with that reported by Hamilton (1976). The interfossil porosity vs. depth curves for the Site 803 samples fall along a single trend, as predicted for a uniform sediment type by Smits et al. (1988). The more scattered picture for the Site 807 samples probably reflects problems with the determination of the intrafossil porosity in material with variable microfossil abundance.

The distinct difference in the level of intrafossil porosity between the two sites is a natural consequence of the greater water depth at Site 803 , which leads to a lower preservation potential for the foraminifers. Because the ooze and chalk trends cannot be separated on the compaction curves (Figs. 6 and 7), no excess preconsolidation at deeper levels caused by chemical compaction can be postulated. Therefore, a calculation of the amount of chemical compaction (Wetzel, 1989) was not attempted.

Apparently, chemical compaction is of only minor importance in the sampled interval. Furthermore, no evidence for chemical compaction was found from SEM or BSE. The growth of larger crystals at the expense of smaller, as described by Schlanger and Douglas (1974), is porosity preserving and does not necessarily indicate chemical compaction. It should be noted that incipient stylolites are found below 470 mbsf in Hole 803D and below 496 mbsf in Hole $807 \mathrm{~A}$. However, none of the tested samples was stylolite bearing.

The difference in strain between the upper and lower halves of the experimental plug samples (Fig. 9) seems primarily a result of wall friction. The strain rate of the tests only leaves time for limited creep or delayed compression (Ruddy et al., 1989). The creep of $1 \%$ strain per decade of time that is estimated from Figure 10 must be taken as a rough estimate. This estimate is valid only when chemical compaction can be disregarded. Also, the scatter of the compaction data partly overlaps the data points representing native samples.

The consolidation curves reported here indicate a rebound $(<0.1 \%)$ that is much lower than the one reported by Hamilton (1976). From a com:varison of log-derived porosities and laboratory data, Urmos, Wilkens, et al. (this volume) also concluded rebound to be of minor importance in the ooze and chalk of Leg 130.

Hamilton (1976) defined a calcareous sediment as a marine sediment containing more than $30 \%$ calcium carbonate. The higher rebound values $(4 \%-5 \%$ at 300 mbsf calculated from a curve with a widely scattered set of data points) reported by Hamilton are probably caused by compositional variations of the sediment. Compression of the oedometers and triaxial cells themselves has been discussed by Jacobsen (1970). However, the effect can be regarded as negligible for the present soft sediments, and no excess rebound is expected because of this effect.

Undrained loading experiments showed no fracture development in the soft ooze samples, whereas conjugate fracture patterns were observed in chalk samples from depths exceeding a natural effective stress of roughly $1.5 \mathrm{MPa}$. Similar fracture patterns were not seen in the reference samples or in the samples that were subjected to drained compaction. It could be argued that the fractures may form as a result of the initial accommodation of the sample to the steel chamber. This seems unlikely because the fractures were not seen in the soft samples that required accommodation, but preferentially in the firm samples where the initial sample was closer to the shape of the chamber.

Lind (1988) postulated that the fractures in the chalk from Stevns were an effect of high pore pressures. A similar mechanism could be proposed here because the fracture patterns in the present vertically drilled samples are similar to the ones seen in horizontally drilled samples from Stevns. For the samples from Stevns, a tensile strength of $0.25 \mathrm{MPa}$ was measured for vertical tension, and $0.5 \mathrm{MPa}$ was measured for horizontal tension. Accordingly, the tensile strength should be less anisotropic in the Ontong Java Plateau material.

\section{SUMMARY}

The loading experiments yielded the following results: 

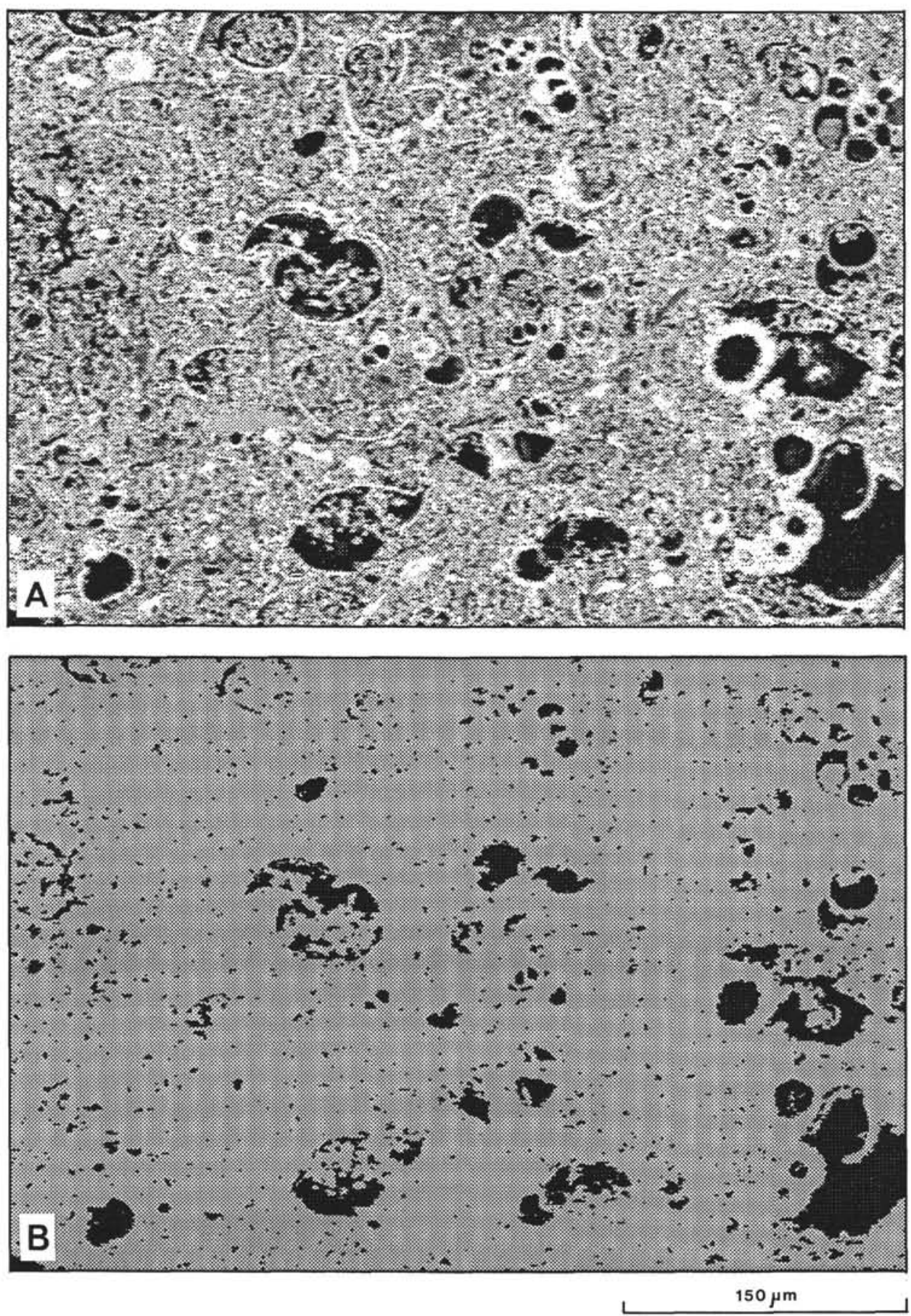

Figure 5. The selection of intrafossil porosity by image analysis. A. Backscatter electron micrograph from Sample 130-803D-56X-2, 144-150 cm. B. The intrafossil porosity selected as the darkest parts of the image.

1. Consolidation curves for the ooze and chalk of Sites 803 and 807 display a scattered pattern. Subtraction of intrafossil porosity from the total porosity, and drawing the consolidation curves as matrix porosity vs. stress, yields a continuous pattern of curves for Site 803. This pattern is similar to that expected for a uniform lithology. Ooze and chalk samples compact along the same trend. This correction is less successful for the Site 807 samples, probably a result of the large variability in microfossil content.

2. The compaction of the samples proceeds from above during the experiments. The strain observed for upper-half samples was about $15 \%$ higher than for lower-half samples. This is probably caused by wall friction. From a comparison of artificial vs. natural compaction (Fig. 10), a creep of roughly $1 \%$ strain per logarithmic decade of time has been estimated.

3. No unequivocal evidence for excess preconsolidation was found, and a calculation of the extent of chemical compaction was therefore not attempted. Chemical compaction is apparently small in the sampled interval.

4. Off-loading curves indicate that the rebound of samples upon removal from their natural state is probably $<0.1 \%$.

5. Samples from depths exceeding a corresponding stress of 1.5 $\mathrm{MPa}$ developed a conjugate fracture pattern when subjected to un- 

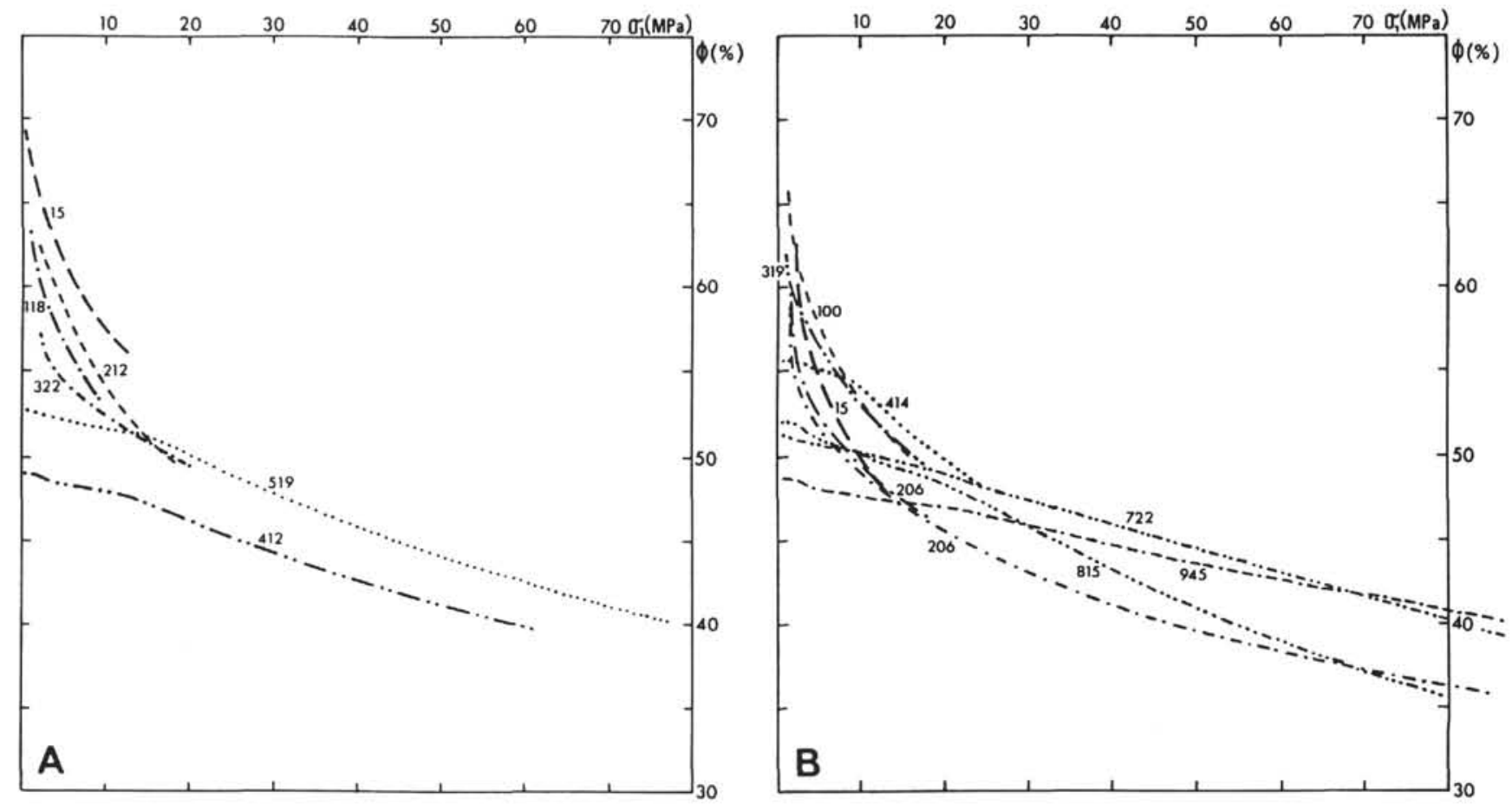

Figure 6. Uniaxial stress, $\sigma_{1}$, vs. porosity, $\phi$, for samples from Holes 803D (A) and 807A and 807C (B). The sample depth for each curve is recorded in meters below seafloor.

drained loading at in-situ fluid pressures. Similar patterns were not seen in consolidated samples or untested reference samples.

\section{ACKNOWLEDGMENTS}

Help and advice are acknowledged from J. Masters, B. Hansen, J. Christensen, H. Diaz, B. Jønsson, V. Knudsen, G. Krarup, E. Schønning, A. Steffensen, I. Søndergaard, P. Wahlberg, and the technical staff of Leg 130. D. Postma assisted with the English.

\section{REFERENCES}

Bachman, R.T., 1984. Intratest porosity in foraminifera. J. Sediment. Petrol., $54: 257-262$.

Fulthorpe, C.S., and Schlanger, S.O., 1989. In situ acoustic properties of pelagic carbonate sediments on the Ontong Java Plateau. J. Geophys. Res., 94:4025-4032.

Hamilton, E.L., 1976. Variations of density and porosity with depth in deep-sea sediments. J. Sediment. Petrol., 46:280-300.

Hamilton, E.L., Bachman, R.T., Berger, W.H., Johnson, T.C., and Mayer, L.A., 1982. Acoustic and related properties of calcareous deep-sea sediments. $J$. Sediment. Petrol., 52:733-753.

Jacobsen, M., 1970. New oedometer and new triaxial apparatus for firm soils. Dan. Geotech. Inst. Bull., 27:7-20.

Kim, D.-C., Manghnani, M.H., and Schlanger, S.O., 1985. The role of diagenesis in the development of physical properties of deep-sea carbonate sediments. Mar. Geol., 69:69-91.
Kroenke, L.W., Berger, W.H., Janecek, T., et al., 1991. Proc. ODP, Init. Repts., 130: College Station, TX (Ocean Drilling Program).

Lind, I.L., 1988. Stylolite formation [Ph.D. dissert.]. Danmarks Tekniske Højskole, Denmark.

Niblack, W., 1986. An Introduction to Digital Image Processing: Englewood Cliffs, NJ (Prentice/Hall)

Ruddy, I., Andersen, M.A., Pattillo, P.D., Bishlawi, M., and Foged, N., 1989. Rock compressibility, compaction, and subsidence in a high-porosity chalk reservoir: a case study of Valhall field. J. Pet. Tech., 41:741-746.

Schlanger, S.O., and Douglas, R.G., 1974. The pelagic ooze-chalk-limestone transition and its implications for marine stratigraphy. In Hsü, K.J., and Jenkyns, H.C. (Eds.), Pelagic Sediments: On Land and Under the Sea. Spec. Publ.-Int. Assoc. Sediment., 1:117-148.

Smits, R.M.M., de Waal, J.A., and van Kooten, J.F.C., 1988. Prediction of abrupt reservoir compaction and surface subsidence caused by pore collapse in carbonates. SPE Form. Eval., 3:340-346.

Wetzel, A., 1989. Influence of heat flow on ooze/chalk cementation: quantification from consolidation parameters in DSDP Sites 504 and 505 sediments. J. Sediment. Petrol., 59:539-547.

Date of initial receipt: 6 September 1991

Date of acceptance: 11 May 1992

Ms 130B-042 
LOADING EXPERIMENTS ON CARBONATE OOZE AND CHALK

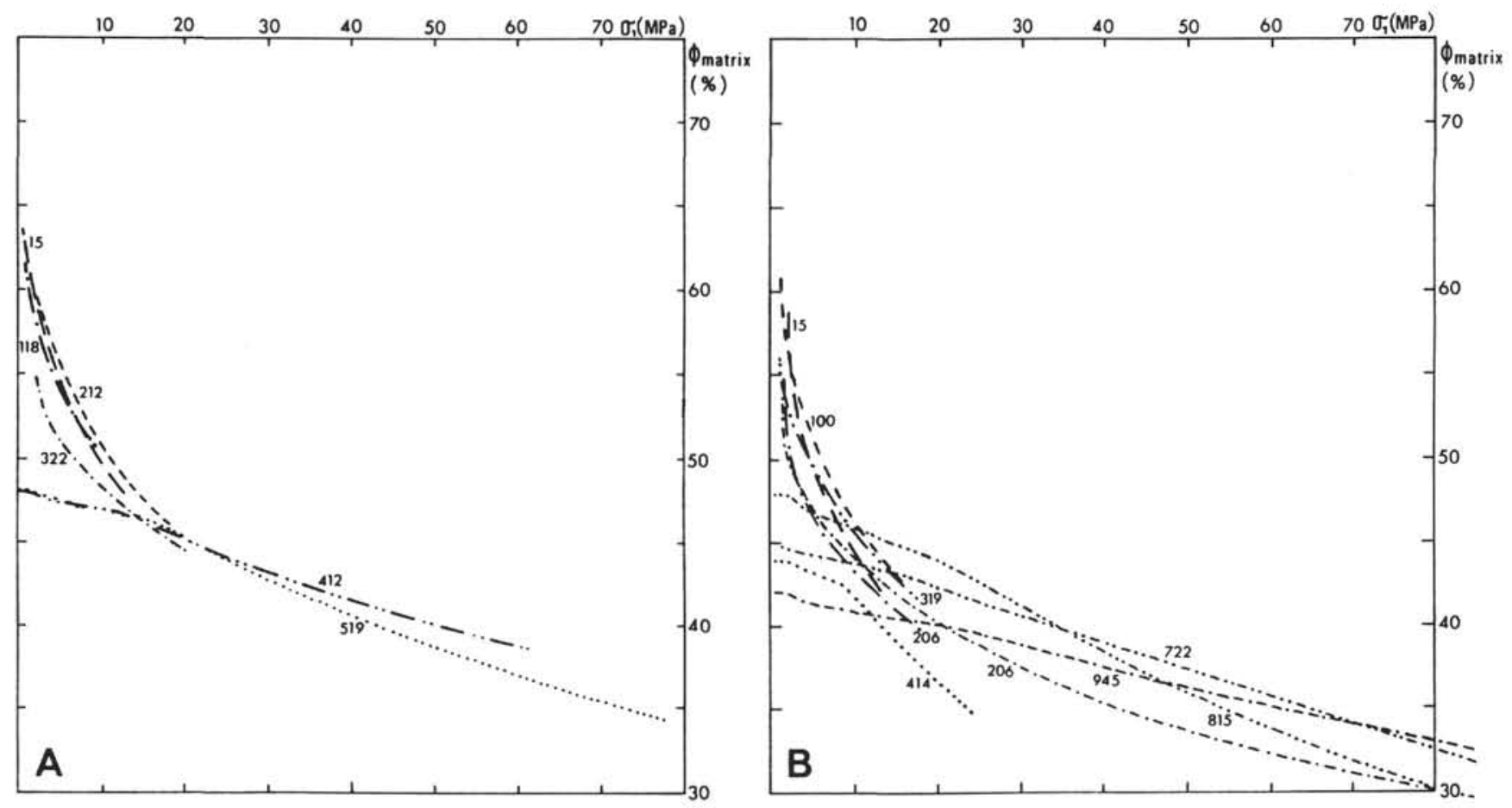

Figure 7. Uniaxial stress, $\sigma_{1}$, vs. matrix porosity, $\phi_{\text {matrix }}$, for samples from Holes $803 \mathrm{D}(\mathbf{A})$ and $807 \mathrm{~A}$ and $807 \mathrm{C}(\mathbf{B})$. The sample depth for each curve is recorded in meters below seafloor.

681 

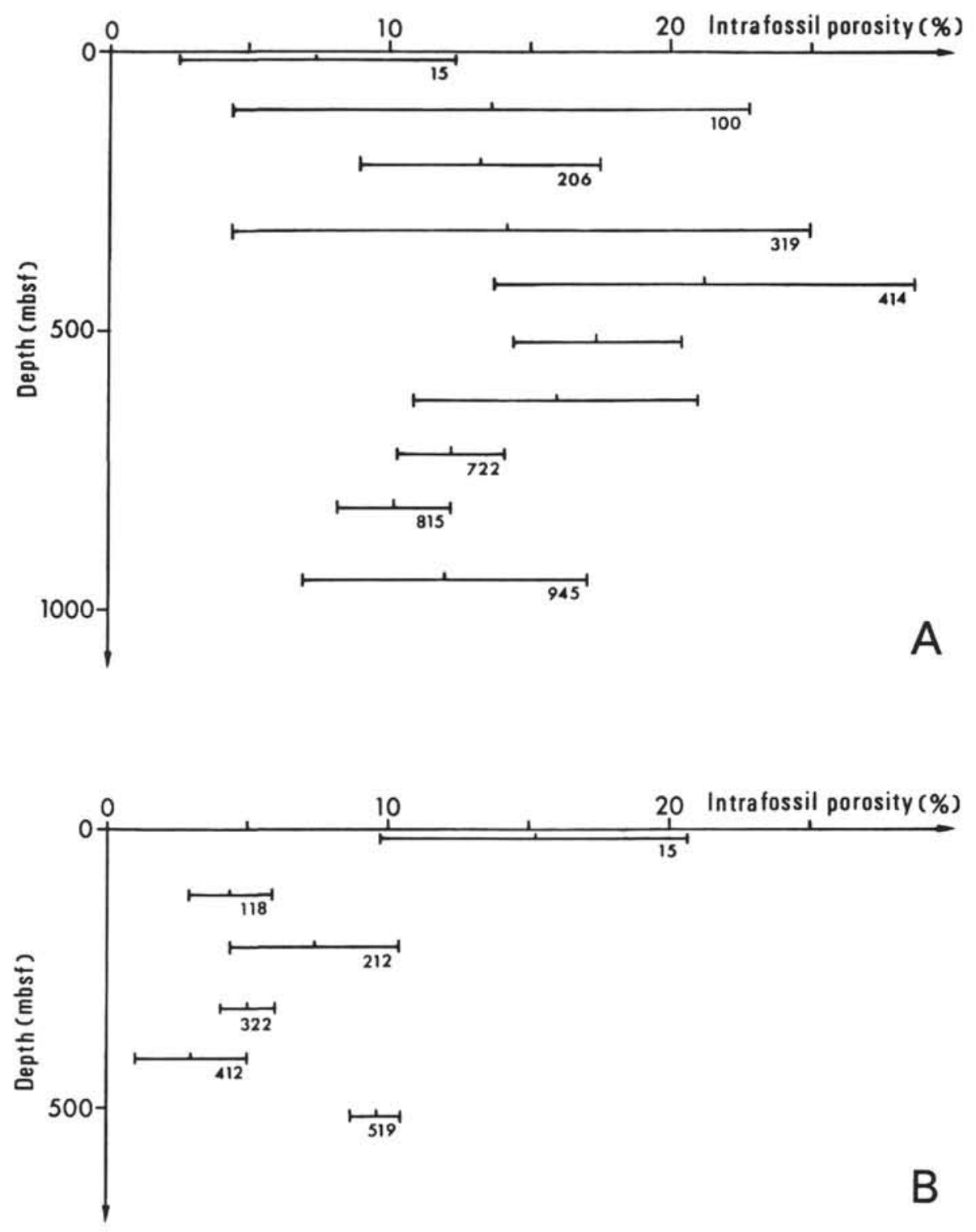

Figure 8. Intrafossil porosity obtained by image analysis of BSE images. The values are given as bars representing 1 standard deviation (SD) on each side of the average value. Sample depths in meters below seafloor are indicated. A. Hole 803D. B. Holes 807A and 807C.

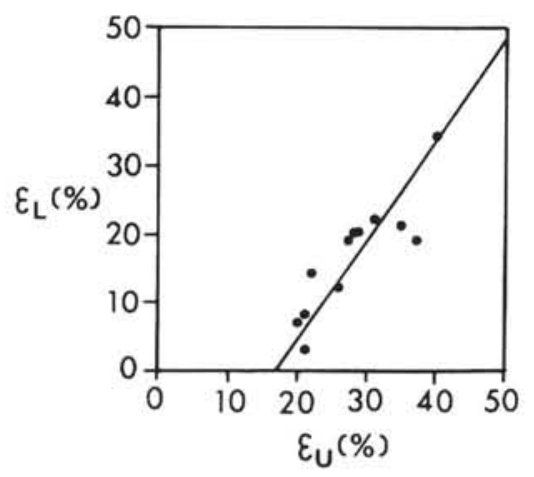

Figure 9. A linear trend is seen in plotting the strain of the lower halves of the sample, $\varepsilon_{\mathrm{L}}$, against the strain of the upper halves, $\varepsilon_{\mathrm{U}}$. 


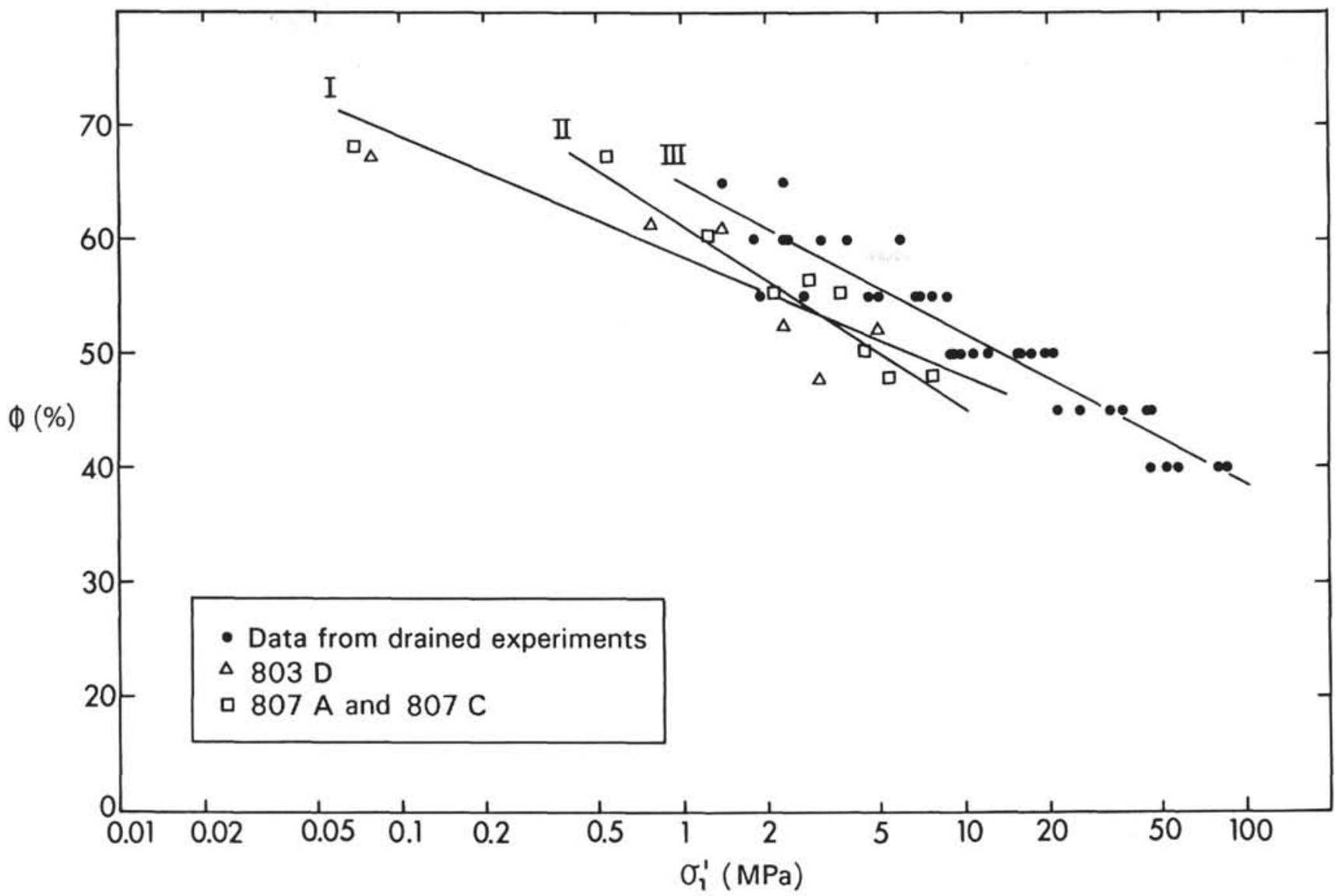

Figure 10. Sample porosity as a function of uniaxial effective stress, $\sigma_{1}{ }^{\prime}$. The data from drained experiments are those recorded during the consolidation tests. They fall roughly along the straight Line III. For the native, uncompacted samples, marked by open symbols, least-squares regression of all the data gives Line I. By leaving out the topmost sample from each hole (where effective uniaxial stress is lowest, and where porosity determination is difficult because of the easily deformable nature of the ooze), the least-squares regression gives Line II.

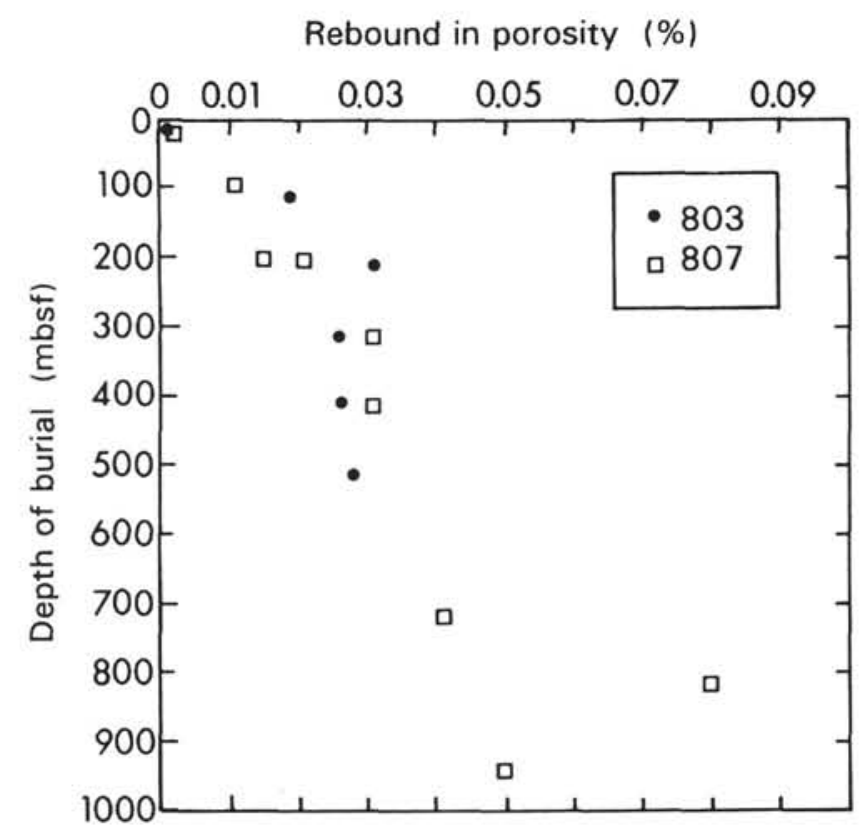

Figure 11. Rebound in the porosity of the samples, caused by removal from their natural state, estimated from consolidation curves following the method of Hamilton (1976). 

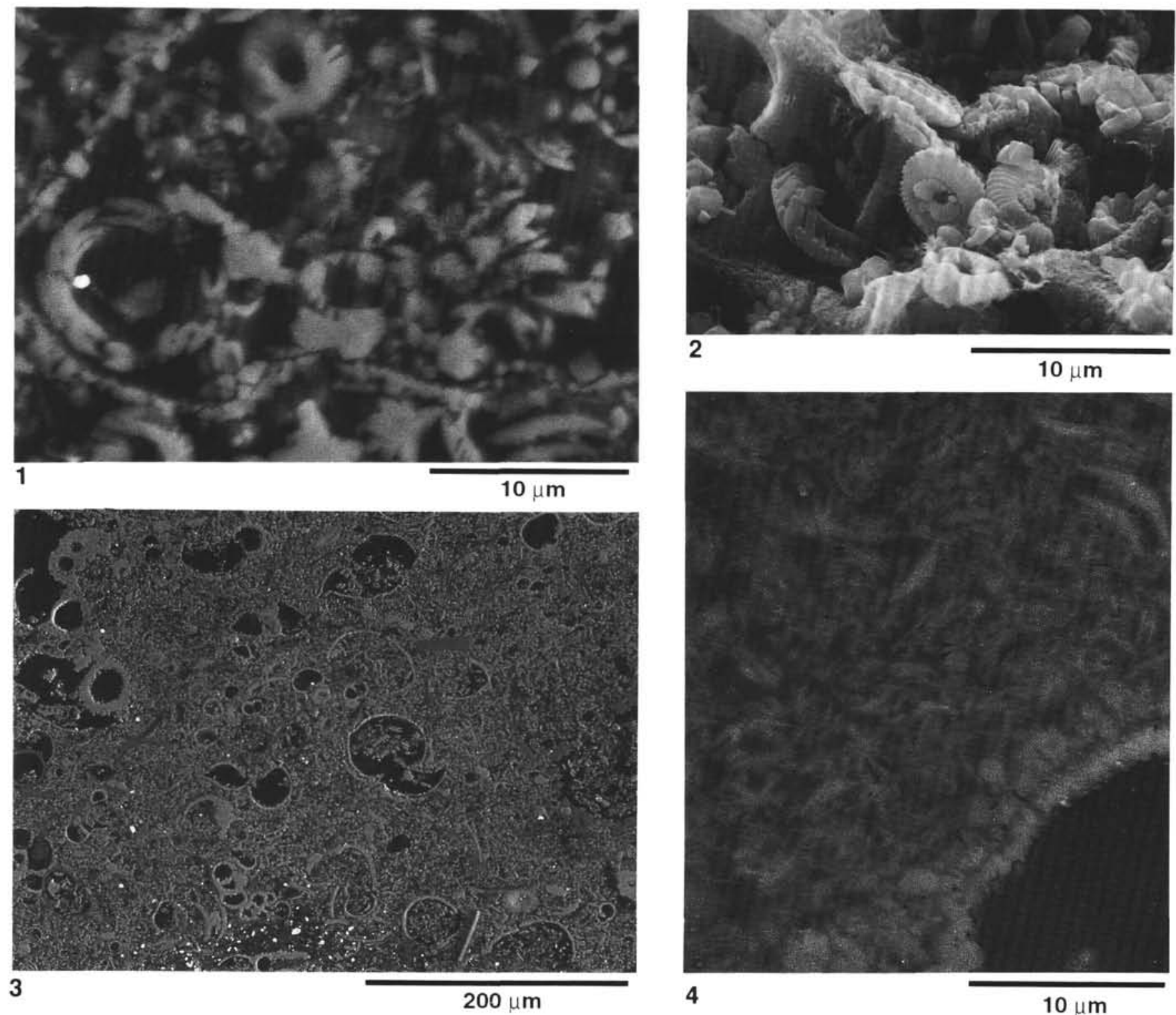

Plate 1. 1-3. Sample 130-803D-56X-2, 144-150 cm (519 mbsf). 4. Sample 130-803D-14H-4, 134-140 cm (118 mbsf). Figure 1 is a BSE image, whereas Figure 2 is a SEM image of the same sample at the same magnification. The shape and packing of the grains are easily seen from the SEM image, whereas the BSE image gives an indication of the matrix porosity. From Figure 3, a BSE image of low magnification, the intrafossil porosity can be estimated by image analysis. The BSE images in Figures 4 and 1 demonstrate the fine grain size of the material near the seafloor and the coarser matrix grain size at deeper burial, respectively. 


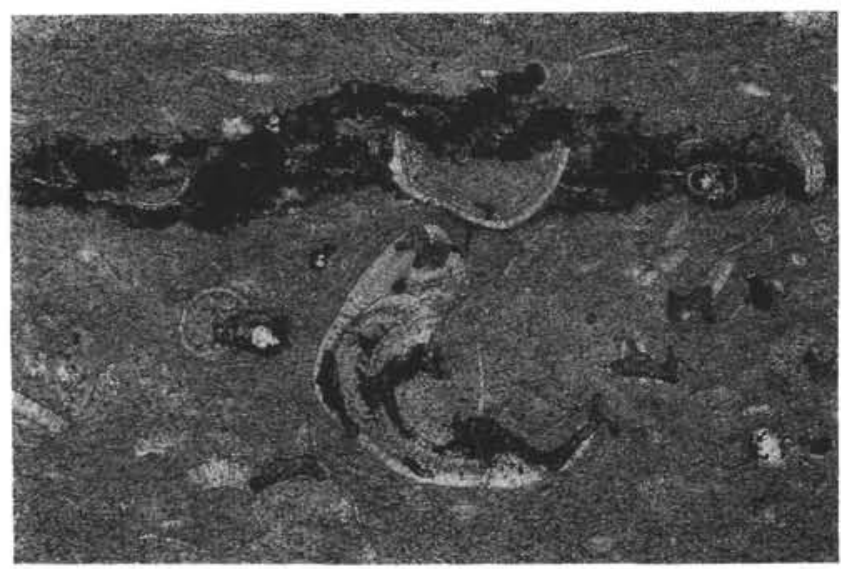

1

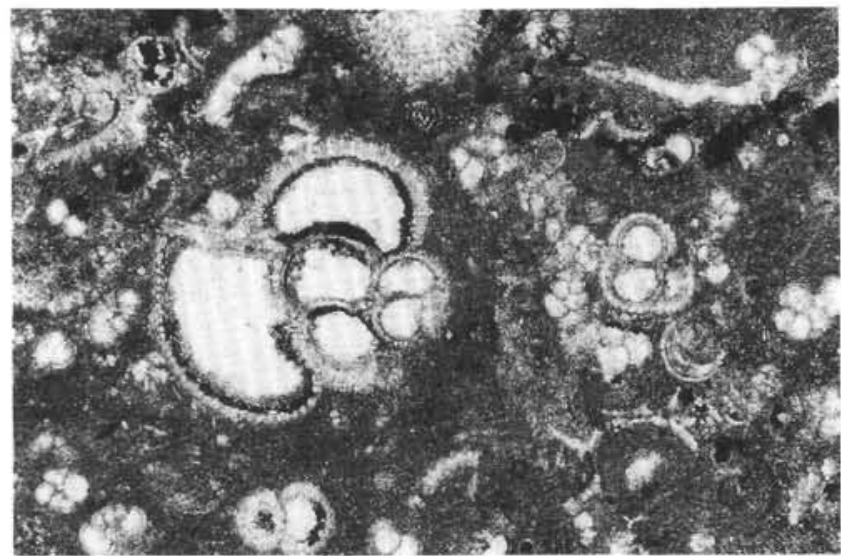

3

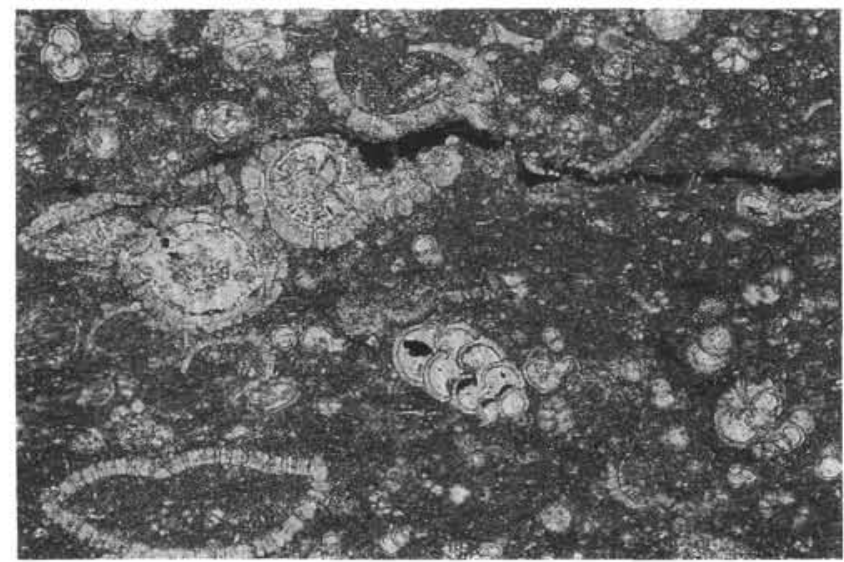

5

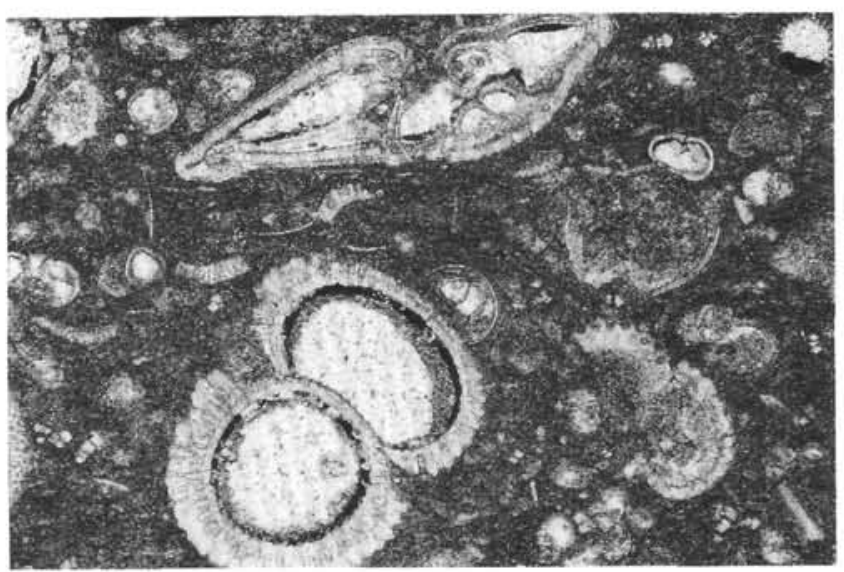

2

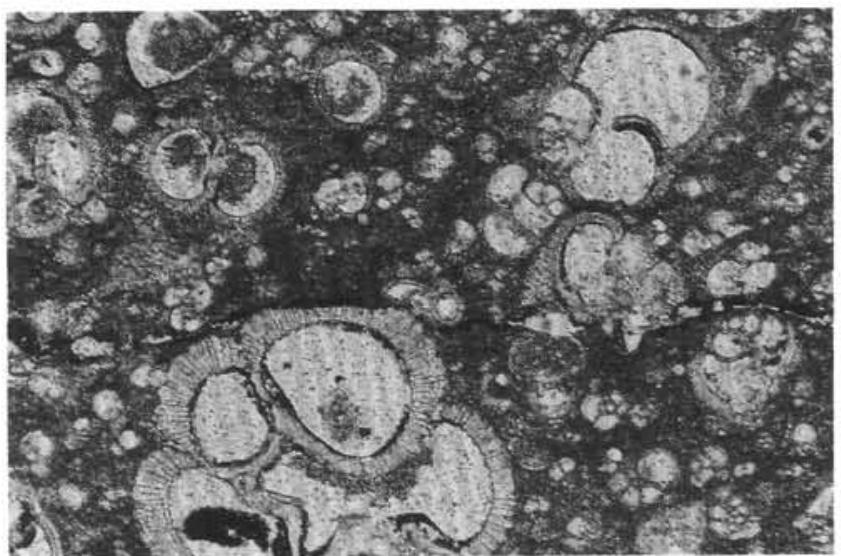

4

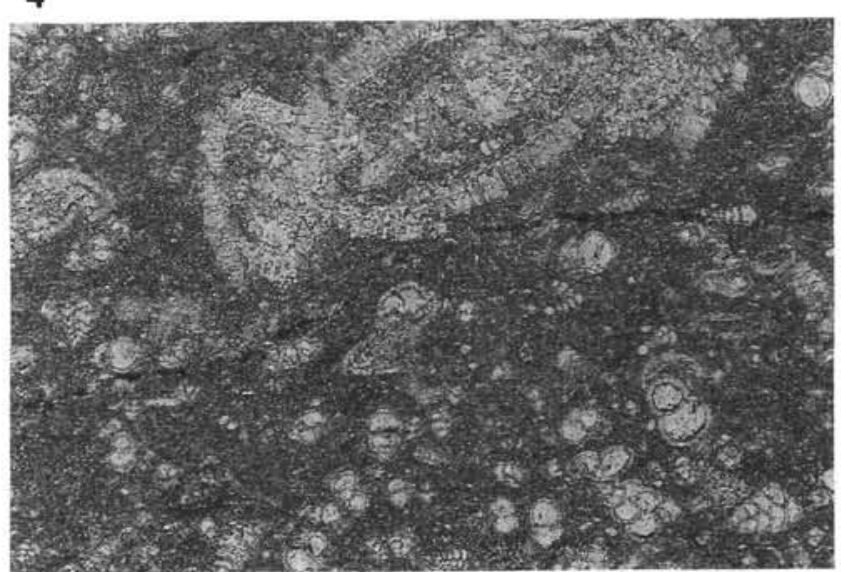

6

\section{$0.5 \mathrm{~mm}$}

Plate 2. Thin-section micrographs of samples from compaction experiments. 1. Sample 130-807A-2H-5, 134-140 cm. 2. Sample 130-807A-11H-5, 134-140 cm. 3. Sample 130-807A-22H-6, 134-140 cm. 4. Sample 130-807A-44X-4, 137-143 cm. 5. Sample 130-807A-76X-4, 43-49 cm. 6. Sample 130-807A$86 \mathrm{X}-1,131-136 \mathrm{~cm}$. The microfossils are preserved whole during compaction. The pyrite coatings are seen as black crystals. The shape of the pyrite seam demonstrates differential compaction near microfossils (Figs. 1, 3, 4, and 5) and microfaulting (Fig. 6). 


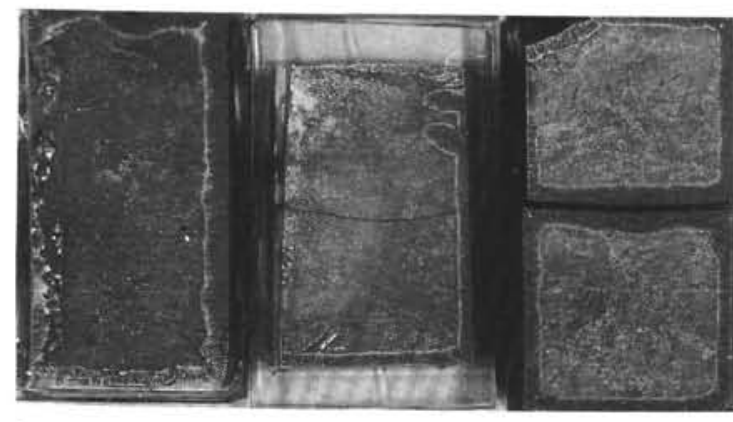

1

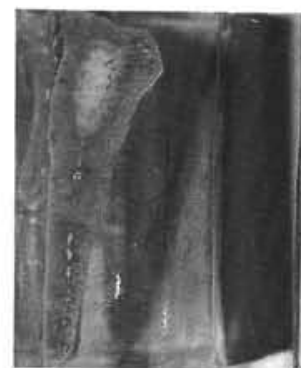

3
$2.5 \mathrm{~cm}$

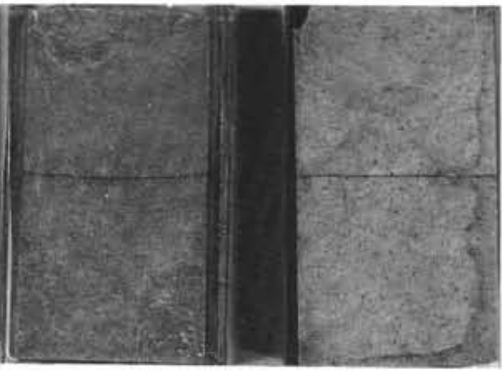

$2.5 \mathrm{~cm}$
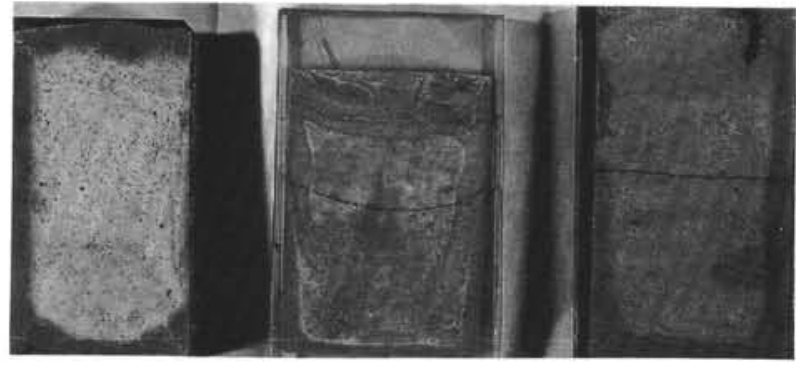

2

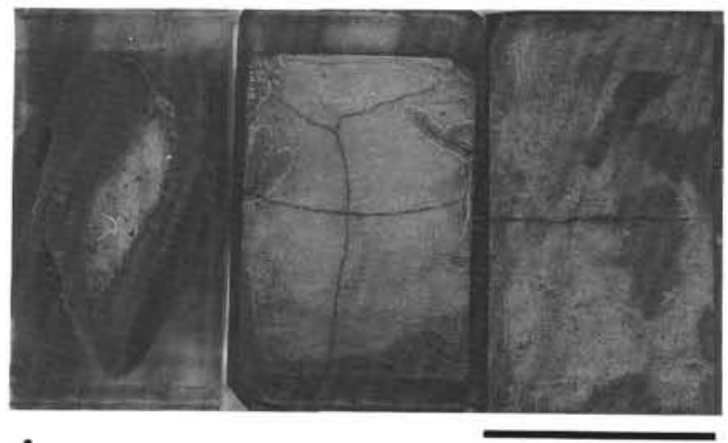

4

$2.5 \mathrm{~cm}$

Plate 3. Polished surfaces of samples after loading experiments. 1. Sample 130-807A-2H-5, 134-140 cm. 2. Sample 130-807A-11H-5, 134-140 $\mathrm{cm}$. 3. Sample 130-807A-44X-4, 137-143 cm. 4. Sample 130-807A-76X-4, 43-49 cm. Reference samples are to the left in each group of three, samples from drained compaction in the middle, and samples from undrained loading to the right. The dark rims around the samples are the result of a two-stage epoxy impregnation. The near-horizontal thin dark lines crossing near the middle of the samples from loading experiments are the pyrite linings. The lines are curved in the compaction samples because of differential compaction. Inclined fractures are seen in the two chalk (Figs. 3 and 4 ) samples subjected to undrained loading. The fractures seen in the reference sample of Figure 1 and in the compacted sample of Figure 4 are formed subsequent to polishing because of stress from the epoxy. 